\title{
Metabolic alterations in human synovial lining cells in pigmented villonodular synovitis
}

\author{
B. HENDERSON, LUCILLE BITENSKY, J. J. JOHNSTONE, \\ A. CAT TERALL, ${ }^{1}$ AND J. CHAYEN
}

From the Division of Cellular Biology, Kennedy Institute of Rheumatology, Bute Gardens, London, and ${ }^{1}$ Department of Orthopaedic Surgery, Charing Cross Hospital, Fulham Palace Road, London

SUMMARY Synovial tissue from 3 patients with villonodular synovitis has been examined by quantitative cytochemistry. Considerable changes in the metabolism of the synoviocytes have been observed. These included a massive rise in the activity of glucose 6-phosphate dehydrogenase to levels even greater than those found in rheumatoid arthritis, and a significant rise in the activity of 2 glycolytic enzymes, glyceraldehyde 3-phosphate and lactate dehydrogenase. Lysosomal napthhylamidase showed raised activity with no latency. The sulphydryl content in the synoviocytes was raised, as was the amount of available phospholipid. This pattern of metabolic alterations is similar to that found in human rheumatoid synoviocytes.

Even in a tissue composed of many cell types, such as rheumatoid synovial tissue, it is possible to measure the biochemical activity of each cell type specifically by means of quantitative cytochemistry. By such procedures apparently characteristic alterations in the metabolism of rheumatoid synoviocytes have been recorded (Chayen et al., 1971; Butcher et al., 1973; Henderson et al., 1978a, b, 1979). During these studies on the metabolic activity of the synovial lining cells biopsies were obtained from 3 patients with unequivocal villonodular synovitis. Since this is a relatively rare condition (Jaffe et al., 1941 ; Byers et al., 1968), the aetiology of which is not established, some aspects of the metabolic activity of the synovial lining cells in these specimens have been investigated.

\section{Clinical details}

Case 1 (specimen 1978). Male, aged 61, with 3-year history of intermittent swelling and pain in the right knee. Pigmented villonodular synovitis, diagnosed by arthroscopy, confirmed at operation.

Case 2 (specimen 1979). Female, aged 66, with 2year history of recurrent pain and swelling of the right knee. Repeated aspirations yielded grossly blood-stained fluid. At arthroscopy pigmented

Accepted for publication 20 October 1978.

Correspondence to Dr B. Henderson, Division of Cellular Biology, Kennedy Institute of Rheumatology, Bute Gardens, London W6 7DW. villonodular synovitis was diagnosed, and this was confirmed histologically on biopsy. An attempt was made to treat the condition by the instillation of $5 \mathrm{mC}$ of ${ }^{90} \mathrm{yttrium}$, but after some amelioration of symptoms for 6 weeks there was a recurrence of swelling and pain of the right knee.

Case 3 (specimen 2055). Female, aged 31. Partial synovectomy of the left knee in 1966, after which the swelling recurred. Synovectomy in 1977, at which the specimen was taken. Through a medial parapatellar incision blood-stained fluid was found. There was gross involvement of the whole of the synovial membrane with pigmented villonodular proliferation. Both femoral and tibial joint surfaces were discoloured and eroded, as was the patella. Both menisci were degenerate.

\section{Materials and methods}

Pieces of synovial tissue, approximately $4 \mathrm{~mm}^{3}$, were chilled by precipitate immersion in $n$-hexane (BDH 'free from aromatic hydrocarbons' grade, boiling range $67-70^{\circ} \mathrm{C}$ ). After not longer than 1 minute the specimens were removed from the hexane and stored at $-70^{\circ} \mathrm{C}$ in corked dry glass tubes. Specimens were sectioned at $10 \mu \mathrm{m}$ in a Bright's cryostat maintained at a cabinet temperature of -25 to $-30^{\circ} \mathrm{C}$ with the knife cooled to $-70^{\circ} \mathrm{C}$ by having solid carbon dioxide packed around its haft. The sections were flash-dried from the knife on to slides taken from the ambient 
temperature of the laboratory (Chayen et al., 1973). To examine the histology some sections were stained with toluidine blue and others with haematoxylin and eosin.

\section{DETECTION OF STRUCTURAL}

REACTIVE GROUPS

Perls's Prussian blue reaction: Sections were treated with a $1 \%$ solution of potassium ferrocyanide (Pearse, 1968); ferric ions $\left(\mathrm{Fe}^{3+}\right)$ in the tissue react with the ferrocyanide to produce the intensely coloured, insoluble ferric ferrocyanide (Prussian blue).

Chèvremont-Frederic reaction: The principle of this method is that sulphydryl groups are such strong reducing agents that they can reduce ferricyanide $\left[\mathrm{Fe}(\mathrm{CN})_{6}\right]^{3-}$ to ferrocyanide $\left[\mathrm{Fe}(\mathrm{CN})_{6}\right]^{4-}$. The latter reacts with ferric ions to produce Prussian blue (as described above). This method gives a measure of the sulphur-containing amino acids which are in the reduced $(-\mathrm{SH})$ state. When serial sections are treated with dithionite (a strong reducing agent) all the oxidised - $\mathrm{SH}$ groups, that is, the disulphide bonds (-S-S-), are reduced to the -SH state and so become reactive with ferricyanide. Thus the total amount of sulphur-containing amino acids in the section can be quantified (Chayen et al., 1973).

Acid haematein reaction: This method is used for the demonstration of unsaturated phospholipids (Chayen, 1968). The method was that described by Chayen et al. (1973).

\section{ENZYME ASSAYS}

The activity of dehydrogenases was measured by the reduction of purified neotetrazolium chloride to yield the insoluble red formazan when the enzyme, in the cells, oxidised its specific substrate in the presence of optimal concentrations of the preferred coenzyme $\left(\mathrm{NADP}^{+}\right.$or $\mathrm{NAD}^{+}$) and the intermediate hydrogen-acceptor phenazine methosulphate. The sections were stabilised by the addition of $20 \%$ polyvinyl alcohol (BO5/140, from Wacker Chemicals Ltd.). Optimal concentrations of reactants for all these procedures, applied to synovial tissue, have been given in the relevant reference. Glucose 6phosphate dehydrogenase, the first and rate-limiting step of the hexose monophosphate shunt, was assayed by the method of Butcher et al. (1973), lactate dehydrogenase (EC 1.1.1.27) by that of Henderson et al. (1978b), and glyceraldehyde 3phosphate dehydrogenase (EC 1.1.1.12) by the procedure of Henderson (1976). The activity of the last two enzymes gives a measure of glycolysis.

Lysosomal naphthylamidase activity and its latency, which is a measure of the state of the lysosomal membranes, were assayed as described by
Bitensky and Chayen (1977). Results are expressed? in terms of percentage bound activity, which is $\overrightarrow{\vec{s}}$ calculated from the expression: (total activity - freeo activity) $\times 100 /$ total activity. The free activity is that found on incubation of sections for a given $\overline{\bar{s}}$ period in the substrate medium. Total activity isp that found when the permeability barrier (to the entry of substrate) of the lysosomal membrane is removed. This is achieved by preincubating sections $\vec{\circ}$ in an acidic buffer, as described by Bitensky and $匚$ Chayen (1977).

\section{MEASUREMENT}

For each reaction 15-20 fields, each containing 2-36 synovial lining cells, were measured in each of duplicate or triplicate sections by means of a Vickers M85 scanning and integrating micro- $\omega$ densitometer $(\times 40$ objective; scanning spot of diameter $0.5 \mu \mathrm{m}$ for measuring the deposits of formazan; $\times 100$ oil immersion objective; scanning? spot of diameter $0.25 \mu \mathrm{m}$ for measuring the reaction? product of naphthylamidase). The integrated relative absorption per unit field, recorded by the micro $\overrightarrow{-} \overrightarrow{0}$ densitometer, was converted to units of absolute integrated extinction per unit field by suitable calibration.

\section{Results}

HISTOLOGY

Patient 1: The synovial lining showed considerable hyperplasia with nodules composed of compressed? synovial villi. In the underlying loose stroma therewere collections of chronic inflammatory cells? which in places had formed into lymphoid follicles Haemosiderin pigment, which gave a positive Perls reaction, was obvious both in the lining cells and ing pigment-filled macrophages.

Patient 2: The specimen showed fairly denseô cellular connective tissue interspersed by cleft-like vascular channels with a hyperplastic synoviaf lining covering the surface. Haemosiderin pigments was abundant. Chronic inflammatory cells were no? evident.

Patient 3: There was marked heterogeneity in the histological appearance of this specimen. In places there was marked nodular villous hyperplasia while in others a more solid connective-tissue vascular mass was present. A striking feature waso giant-cell transformation of the lining cells both in the lining layer and deep to it. In both the villous? and more solid areas the sublining cell tissue con-0 tained dense infiltrates of foamy macrophages which? stained with the fat-dye, oil red $O$. Haemosidering pigment was abundant in the lining cells, giant cells $\mathbb{D}$ and macrophages. There was no evidence of chronice inflammatory cell infiltrate. 


\section{BIOCHEMICAL ACTIVITIES}

Glucose 6-phosphate dehydrogenase activity was remarkably high (Table 1), being equal to, or far exceeding, the greatest activity found in rheumatoid synoviocytes.

Table 1 Glucose 6-phosphate dehydrogenase activity in synovial lining cells

\begin{tabular}{ll}
\hline Tissue & $\begin{array}{l}\text { Enzyme activity } \\
\left.\text { (Integrated extinction } \times 10^{3} / 10 \mathrm{~min}\right)\end{array}$ \\
\hline Villonodular synovitis: & \\
Specimen No. 1978 & 1338 \\
1979 & 1295 \\
2055 & 606 \\
Nonrheumatoid & $119 \pm 93(\mathrm{n}=14)^{*}$ \\
(mean \pm SD) & $106 \pm 22(\mathrm{n}=8) \dagger$ \\
Rheumatoid & $496 \pm 209(\mathrm{n}=18)^{*}$ \\
(mean \pm SD) & $432 \pm 12(\mathrm{n}=7) \dagger$ \\
\hline
\end{tabular}

*Results of Henderson (1977). †Results of Butcher et al. (1973).

The total lysosomal naphthylamidase activity, measured after removal of the influence of the lysosomal membrane, was also markedly raised in the synoviocytes in these specimens (Table 2). Almost all of this activity was manifest activity: specimens 1979 and 2055 had no measurable latent activity, and the lysosomes in the synoviocytes in specimen 1978 showed $5 \%$ latent activity.

The activities of two glycolytic enzymes, glyceraldehyde 3-phosphate and lactate dehydrogenase, were markedly raised over those found in relatively normal synovial lining cells (Table 3 ).

In the 1 specimen examined (No. 1979) all the sulphur-containing amino acids were in the reduced $(-\mathrm{SH})$ state in that reduction with dithionite did not increase the reaction for sulphydryl groups. The acid haematein reaction for freely available phospholipids gave fairly strong responses in all three specimens.

Table 2 Total naphthylamidase activity in synovial lining cells

\begin{tabular}{|c|c|c|}
\hline Tissue & $\begin{array}{l}\text { Enzyme activity } \\
\text { (Int. ext. } \times \\
1000 / 15 \mathrm{~m})\end{array}$ & $\begin{array}{l}\text { Rel. abs./unit } \\
\text { field/30 m† }\end{array}$ \\
\hline \multicolumn{3}{|l|}{ Villonodular synovitis } \\
\hline $\begin{array}{r}\text { Specimen No: } 1978 \\
1979 \\
2055\end{array}$ & $\begin{array}{r}533 \\
698 \\
1040\end{array}$ & \\
\hline $\begin{array}{l}\text { Non-rheumatoid (mean } \pm S D \text { ) } \\
\text { Non-rheumatoid after recent } \\
\text { trauma (mean } \pm S D \text { ) }\end{array}$ & $232 \pm 10(n=4)^{*}$ & $\begin{array}{l}140 \pm 63(n=9) \\
312 \pm 93(n=8)\end{array}$ \\
\hline Rheumatoid (mean \pm SD) & $358 \pm 75(n=4)^{*}$ & $223 \pm 93(n=18)$ \\
\hline
\end{tabular}

* Results of Henderson (1977). †Results of Chayen et al. (1971). Although it is not possible to relate these values of 'relative absorption' to 'integrated extinction', the former values are given as an indication of the degree to which recent trauma and the rheumatoid state affect this activity.
Table 3 The activities of lactate dehydrogenase $(L D H)$ and glyceraldehyde 3-phosphate dehydrogenase (GAPD)

\begin{tabular}{|c|c|c|}
\hline Tissue & $\begin{array}{l}\text { Enzyme activity } \\
1000 / 10 \mathrm{~m}) \\
\text { GAPD }\end{array}$ & $\begin{array}{l}\text { int. ext. } \times \\
L D H\end{array}$ \\
\hline \multicolumn{3}{|l|}{ Villonodular synovitis } \\
\hline $\begin{array}{r}\text { Specimen No. } 1978 \\
1979 \\
2055\end{array}$ & $\frac{54}{333}$ & $\begin{array}{l}- \\
464 \\
686\end{array}$ \\
\hline $\begin{array}{l}\uparrow \text { Nonrheumatoid } \\
\text { †Rheumatoid }\end{array}$ & $\begin{array}{c}9 \pm 8(n=6)^{*} \\
110 \pm 84(n=7)^{*}\end{array}$ & $\begin{array}{l}156 \pm 77(n=6)^{*} \\
654 \pm 328(n=14)^{*}\end{array}$ \\
\hline
\end{tabular}

†Results expressed as mean \pm SD. ${ }^{*}$ Results of Henderson et al. (1978c). - means not measured.

\section{Discussion}

Presumably because this disease is uncommon, no biochemical studies have been reported on the metabolism of synoviocytes in pigmented villonodular synovitis. The results in 3 cases investigated in the present study indicate that major metabolic alterations occur in these cells in this condition. Glucose 6-phosphate dehydrogenase activity was considerably raised (Table 1), even above the values found in synoviocytes of rheumatoid synovial tissue (Butcher et al., 1973; Henderson, 1977). Lysosomal latency (bound naphthylamidase activity) was virtually nonexistent, very much as was found by Chayen and Bitensky (1971) with synoviocytes of rheumatoid synovial tissue (bound activity of $1 \%$, range: $0-5 \%, \mathrm{n}=13$ as against $44 \%$ for nonrheumatoid synoviocytes, range: $31-57 \%, \mathrm{n}=8$ ). Total lysosomal naphthylamidase activity was markedly increased even over that found in synovial cells lining rheumatoid synovial tissue (Table 2). This increased content of a lysosomal enzyme is in accord with these cells engulfing nondigestible matter (Dingle, 1975). The activities of both glycolytic enzymes studied were of the levels found in rheumatoid synoviocytes, which Henderson et al. (1978b) showed to be higher than in synovial lining cells from joints free from rheumatic disease. Similarly the -SH:-S-S ratio (almost $100 \%$ sulphydryl) and the availability of cellular phospholipids (the acid haematein reaction) were very much as have been found in rheumatoid but not nonrheumatoid synovial lining cells (Butcher et al., 1973; Henderson et al., 1978a). Thus the metabolic behaviour of the synovial lining cells in these 3 specimens of villonodular synovitis was similar to, or exaggerated above, that found previously as typical of the synoviocytes of rheumatoid tissue.

It has been argued, for example, by Chayen and Bitensky (1971), that the biochemical changes in the synoviocytes, previously considered characteristic for rheumatoid tissue, were related to the erosion of cartilage and joint destruction. There is some 
evidence (McMaster, 1960; Schajowicz and Blumenfeld, 1968) that villonodular synovitis, if left untreated for a sufficient time, can also produce such changes. Certainly in case 3 (No. 2055) both femoral and tibial joint surfaces as well as the surface of the patella were found at operation to be discoloured and eroded, and both menisci were degenerate. Moreover, there is a degree of similarity between villonodular synovitis and haemophiliac arthropathy, in which the destruction of the joint is common (Creveld et al., 1971; Mainardi et al., 1978). Consequently the biochemical findings in these cases of villonodular synovitis are not inconsistent with the view that such changes may be associated with the degradation of joints.

We gratefully acknowledge support for this work from the Medical Research Council and from the Arthritis and Rheumatism Council for Research.

\section{References}

Bitensky, L., and Chayen, J. (1977). Histochemical methods for the study of lysosomes. Lysosomes, A Laboratory Handbook, 2nd edn., p. 209. Edited by J. T. Dingle, North Holland: Amsterdam.

Butcher, R. G., Bitensky, L., Cashman, B., and Chayen, J. (1973). Differences in the redox balance in human rheumatoid and non-rheumatoid synovial lining cells. Beiträge zur Pathologie, 148, 265-274.

Byers, P. D., Cotton, R. E., Deacon, O. W., Lowry, M., Newman, P. H., Sissons, H. A., and Thomson, A. D. (1968). The diagnosis and treatment of pigmented villonodular synovitis. Journal of Bone and Joint Surgery, 50B, 290-305.

Chayen, J. (1968). The histochemistry of phospholipids and its significance in the interpretation of the structure of cells. In Cell Structure and its Interpretation, p. 149. Edited by S. M. McGee-Russell and K. F. A. Ross. Edward Arnold: London.
Chayen, J., and Bitensky, L. (1971). Occasional survey lysosomal enzymes and inflammation with particular: reference to rheumatoid disease. Annals of the Rheumatiक Diseases, 30, 522-536.

Chayen, J., Bitensky, L., Butcher, R. G., and Cashman, BC (1971). Evidence for altered lysosomal membranes in synovial lining cells from human rheumatoid joints Beiträge zur Pathologie, 142, 137-149.

Chayen, J., Bitensky, L., and Butcher, R. G. (1973). Practicaf Histochemistry. Wiley: London.

Creveld, S. V., Hoedemaeker, Ph. J., Kingma, M. J., anc Wagenvoort, C. A. (1971). Degeneration of joints in haemophiliacs under treatment by modern methods. Journat of Bone and Joint Surgery, 53B, 296-302.

Dingle, J. T. (1975). The secretion of enzymes into the perio cellular environment. Philosophical Transactions of tho Royal Society of London, 271, 315-324.

Henderson, B. (1976). Quantitative cytochemical measure ment of glyceraldehyde 3-phosphate dehydrogenase activity. Histochemistry, 48, 191-204.

Henderson, B. (1977). Quantitative cytochemical studies of rheumatoid arthritis. Ph.D. thesis, Brunel University.

Henderson, B., Bitensky, L., and Chayen, J. (1978a). Altered. phospholipids in human rheumatoid synoviocytes. Annalo of the Rheumatic Diseases, 37, 24-29.

Henderson, B., Bitensky, L., and Chayen, J. (1978b). Mito음 chondrial oxidative activity in human rheumatoid synovia佂 lining cells. Annals of the Rheumatic Diseases, 37, 548-551.

Henderson, B., Bitensky, L., and Chayen, J. (1979). Glycolye tic activity in human synovial lining cells in rheumatoido arthritis. Annals of the Rheumatic Diseases, 38, 63-67.

Jaffe, H. L., Lichtenstein, L., and Sutro, C. J. (1941). Pigo mented villonodular synovitis, bursitis and tenosynovitis Archives of Pathology, 31, 731-765.

Mainardi, C. L., Levine, P. H., Werb, Z., and Harris, E. D (1978). Proliferative synovitis in haemophilia: biochemica and morphological observations. Arthritis and Rheumatism, 21, 137-144.

McMaster, P. E. (1960). Pigmented villonodular synovitiş with invasion of bone. Journal of Bone and Joint Surgery 42A, 1170-1183.

Pearse, A. G. E. (1968). Histochemistry, Theoretical and Applied, Vol. 1, p. 6. Churchill: London.

Schajowicz, F., and Blumenfeld, I. (1968). Pigmente villonodular synovitis of the wrist with penetration inte bone. Journal of Bone and Joint Surgery, 50B, 312-317. 